http://e-journal.stit-islamic-village.ac.id/index.php/JECIES

\title{
REVITALISASI PENDIDIKAN KARAKTER PADA ANAK USIA DINI UNTUK MENCIPTAKAN GENERASI UNGGUL
}

\author{
Leni Nurmiyanti \\ Program Studi Pendidikan Anak Usia Dini STIT Islamic Village Tangerang \\ Email: \\ leninurmiyanti.stit@gmail.com
}

Received: 18 Maret, 2021.

Accepted: 29 Maret, 2021.

Published: 31 Maret, 2021

\begin{abstract}
Activating the national character of the nation's generation from an early age in an are that is developing so rapidly is a prosess that requires seriousness and collective awareness. Characrter education is a part that must be built since early childhood, this period is a golden age for children to be given a stimulus in coaching, learning, understanding and character building which will later become the main capital for them in the future. Children are the next generation who will fight for and defend their nation, thus of course it is very important for all elements of society to be responsible for creating a generation of hope for a nation with quality and character. The creation of a superior generation that will be able to build an advanced civilization is certainly not an easy thing. It takes seriousness and consistency in supporting the educational prosess that will be given to the nation's generation. The prosess of early childhood education must be developed and planned with a good planned, good organized pattern of education. The educational prosess obtained by the nation's generation is of course a prosess that runs continuously and continues until the child is an adult, the prosess of shaping the future of the nation will certainly require time and an interrelated struggle between elements of society. Collective awareness and high willingness will help facilitate the educational prosess of children as the nation's future generations.
\end{abstract}

Keywords: Revitalization, Character Education

\begin{abstract}
ABSTRAK
Mengaktifasikan karakter bangsa harus dibangun sejak masa anak usia dini, dimana masa tersebut merupakan masa keemasan bagi anak untuk dapat diberikan stimulus dalam pendidikan, pembelajaran, pemabaman serta pembentukan karakter yang nantinya akan menjadi modal utama dalam diri mereka dimasa yang akan datang. Anak merupakan generasi selanjutnya yang akan memperjuangkan dan mempertabankan bangsanya, dengan demikian tentunya sangat penting bagi semua elemen masyarakat bertanggung jawab secara kolektif dalam menciptakan generasi barapan bangsa yang berkualitas dan berkarakter. Terciptanya generasi unggul yang mampu membangun peradaban maju tentunya bukan hal yang mudah. Dibutubkan keseriusan dan konsistensi dalam mendukung proses pendidikan yang akan diberikan kepada generasi bangsa. Proses pendidikan anak usia dini barus dikembangkan dan direncanakan dengan pola pendidikan yang terencana dan
\end{abstract}


terorganisir dengan baik. Proses pendidikan yang diperoleh generasi bangsa tentunya merupakan proses yang berjalan terus menerus dan berlanjut bingga anak beranjak dewasa, proses pembentukan masa depan bangsa tentunya akan membutubkan waktu dan perjuangan yang saling terkait antar elemen masyarakat. Kesadaran kolektif dan kemauan yang tinggi akan membantu memfasilitasi proses pendidikan anak-anak sebagai generasi penerus bangsa.

Kata Kunci: Revitalisasi, Pendidikan Karakter

\section{PENDAHULUAN}

Revolusi intustri 5.0 yang terus bergerak menghantarkan perubahan zaman yang kian cepat. Perubahan tersebut menghadirkan dua mata pisau yang tajam bagi perkembangan masa depan generasi bangsa. Tidak hanya perubahan positif, namun juga perubahan negatif yang perlu menjadi perhatian setiap elemen masyarakat. Hadirnya perkembangan teknologi yang kurang disadari manfaat serta kegunanya dalam mendukung pendidikan anak bangsa, menghadirkan dekadensi moral yang membuat keresahan dalam perkembangan kemajuan dunia pendidikan. Terjadinya pergeseran memahaman akan kemajuan zaman, membutuhkan pendidikan karakter dalam merevitalisasi perkembangan jiwa anak-anak yang nantinya akan menjadi generasi penerus harapan bangsa. Pendidikan karakter yang ditanamkan sejak anak usia dini merupakan usaha yang dilaksanakan secara berkesadaran dalam memaksimalkan perkembangan potensi diri anak manusia, untuk menghantarkan menjadi manusia yang utuh (kaffah), yang kelak akan menjadi generasi unggul harapan bangsa.

Generasi Unggul merupakan manusia yang mencintai kebenaran dan mencari kebenaran, untuk mendapatkan kebenaran anak manusia hendaknya mencintai kebijaksanaan. Kebijaksanaan dalam diri tentunya didapat dari pengetahuan dan pengalaman dalam kehidupannya sejak lahir hingga dewasa. Pada hakikatnya anak manusia merupakan mahluk individual, namun selain itu ia juga merupakan sebagai makhluk sosial. Sehingga apa yang terjadi didalam diri anak manusia akan berdampak dan berpengaruh dalam mental dirinya. Segala yang mereka ketahui dari proses belajar melalui pengalamannya akan menjadi sumber pengetahuan, secara perlahan anak manusia akan memaksimalkan segala potensi yang dimilikinya. Semakin banyak pengetahuan yang dimiliki akan meningkat pula intelektualitas dan pemahaman akan eksistensi dirinya sebagai manusia.

Pendidikan karakter merupakan proses berkelanjutan dan berkesinambungan yang tidak akan pernah berakhir dan terdapat pula prinsip "long life education", apa yang terjadi dan dipahami oleh manusia akan terus meningkat sejalan dengan pengetahuan yang dimilikinya. Proses perbaikan dan evaluasi diri akan menghasilkan kualitas yang berkesinambungan, kualitas diri tersebut ditujukan pada peningkatan pemahaman ilmu pengetahuan dan akan

JECIES: Journal of Early Childhood Islamic Education Study

Vol. 02, Nomor 01, Maret 2020 
teraktual pada lakuguna dalam eksistensi diri. Terwujudnya sosok generasi unggul bangsa yang memahami tentang teori dan konsep nilai, serta melaksanakannya hingga menjadi kebiasaan (habit) dalam diri anak manusia. Pendidikan karakter hendaknya mampu menumbuh kembangkan nilai-nilai filosofis dan mengamalkan seluruh karakter bangsa secara utuh (kaffah) dan menyeluruh, sehingga anak-anak yang telah dididik sejak usia dini dengan baik dan benar akan menjadi harapan bangsa yang berkarakter. Bangsa besar adalah bangsa yang karakter dan memiliki identitas diri sehingga tidak mudah dijajah oleh bangsa lain, generasi bangsa akan menjaga kedaulatan bangsa.

\section{METODE}

Metode yang digunakan dalam pengumpulan data adalah metode Library Research. Dengan cara pengumpulan data-data yang sesuai dengan judul tersebut, kemudian data yang telah terkumpul direduksi secara deduktif untuk kemudian dipadukan dan disesuaikan dengan konsep pendidikan karakter anak usia dini. Pembahasan hasil akan dipaparkan secara deskriptif dengan Teknik analisis data menggunakan metode Content Analysis.

\section{HASIL DAN PEMBAHASAN \\ Pendidikan Karakter}

Kata pendidikan karakter merupakan pengabungan dua kata, yang berasal dari kata pendidikan dan karakter. Kata "Pendidikan" yang tertuang dalam Undang-undang Sisdiknas No.20 Tahun 2003 merupakan penyempurnaan dari pengertian pendidikan pada undang-undang sebelumnya. Pendidikan dijelasakan dalam didalam UU 20 Tahun 2003 pada Bab 1 berbunyi: "Pendidikan adalah usaha sadar dan terencana untuk mewujudkan suasana belajar dan proses pembelajaran agar peserta didik secara aktif mengembangkan potensi dirinya untuk memiliki kekuatan spiritual keagamaan, pengendalian diri, kepribadian, kecerdasan, akhlak mulia, serta keterampilan yang diperlukan dirinya, masyarakat, bangsa dan negara"(UU No.20 : 2000). Dalam Kamus Bahasa Indonesia kata "Pendidikan" berasal dari kata didik yang mendapatakan imbuhan "Pen" dan akhiran "an". Kata tersebut dijelasakan dalam Kamus Besar Bahasa Indonesia (KBBI) " Proses pengubahan sikap dan tata laku seseorang atau kelompok orang dalam usaha mendewasakan manusia melalui uapaya pengajaran dan pelatihan; proses, cara, perubuatan mendidik" (KBBI Online). Berdasarkan pengertian tersebut dapat diartikan bahwa pendidikan merupakan proses yang dilaksanakan orang dewasa kepada manusia yang belum dewasa secara sistematis dan berkesadaran, untuk menghantarkan anak manusia menjadi manusia 
seutuhnya. Melalui pendidikan menghantarkan pengetahuan pada anak didik yang membuat perubahan di dalam diri peserta didik.

Dalam Bahasa Inggris Pendidikan diterjemahkan dengan kata education sedangkan kata pengajaran digunakan dengan kata teaching. Secara semantik (Kebahasaan) dari kata pendidikan, pengajaran (education atau teaching) sebagaimana disebutkan jika diperhatikan secara seksama, nampak bahwa kata-kata tersebut lebih menunjukkan pada suatu kegiatan atau proses yang berhubungan dengan pembinaan yang dilakukan oleh seseorang kepada orang lain (Natta Abuddin:1997).

Sedangkan dalam Bahasa Arab kata pendidikan juga dapat dijumpai dengan kata tarbiyah dalam bahasa Arab. Pedidikan dari sudut pandang Islam disebut at-Tarbiyah, secara harfiah kata tarbiyah berasal dari akar kata robbaya menjadi robba kemudian ditasrif (infinitif) menjadi 'yurabbi' dan 'tarbiyatan' atau 'tarbiyah' (bacaan/ucapan huruf waqof). Dalam kamus popular bahasa Arab, seperti kamus 'al-Misbah al-Munir (Kamus klasik yang menjadi rujukan ahli-ahli tafsir Qur'an), dan Mukhtar ash-Shihah (kamus mutakhir yang sering menjadi referensi), serta al-Munjid, menulis pengertian rabba dalam berbagai versi dengan dua pengertian. Pertama dalam pengertian pengasuh dan kedua dalam pengertian pemberian makanan ( Nasution Faruq : 2011). Naquib alAttas berpendapat bahwa kata yang paling tepat untuk mewakili kata pendidikan adalah kata ta'dib, semetara Tarbiyah dinilainya terlalu luas, yakni mencakup pendidikan untuk hewan. Sedangkan kata ta'dib sasaran pendidikannya adalah manusia (Natta Abuddin:1997). Berdasarkan pengertian diatas maka penulis mensintesiskan bahwa pendidikan adalah usaha sadar dan terencana yang dilakukan oleh orang dewasa dalam membimbing dan mengarahkan kepada anak didiknya dari yang tidak tahu menjadi tahu, yang tidak paham menjadi paham, yang tidak mengerti menjadi mengerti sehingga mencapai pemahaman secara menyeluruh untuk modal dalam kehidupan anak didik kelak. Setelah membahas apa itu pendidikan, yang kedua penulis akan membahas apa itu "karakter". Dalam tulisan ini penulis hendak menjelakan secara singkat masing-masing arti kata yang merupakan kajian dalam tulisan ini.

Kata" karakter" dalam KBBI mengandung arti : bawaan, prilaku, personalitas, sifat, tabiat atau ciri, karakteristik, keunikan (KBBI Online). sedangkan menurut Wynne (1991) yang dikutip oleh E. Mulyasa mengemukakan bahwa karakter berasal dari Bahasa Yunani yang berarti "to mark" (menandai) dan memfokuskan pada bagian mana menerapkan nilainilai kebaikan dalam tindakan nyata atau prilaku sehari-hari (Mulyasa. E :2011). Sejalan dengan pengertian karakter yang sebelumnya telah disebutkan, Dirjen Pendidikan Agama Islam Kementrian Agama Republik Islam (2010) mengemukakan bahwa karakter (character) dapat diartikan sebagai totalitas 
ciri-ciri pribadi yang melekat dan dapat diidentifikasi pada perilaku individu yang bersifat unik, dalam arti secara khusus ciri-ciri ini membedakan antara satu individu dengan perilaku yang lainnya. Karena ciri-ciri karakter tersebut dapat diidentifikasi pada perilaku individu dan bersifat unik, maka karakter sangat dekat dengan kepribadian individu (Mulyasa.E:2011). Dengan demikian kata karakter berdasarkan definisi sebelumnya erat hubungannya dengan kepribadian seseorang yang melekat dalam diri manusia, yang menjadikan dirinya unik dan berbeda dengan manusia lainnya. Seorang yang berkepribadian tersebut adalah seseorang yang menghargai nilai-nilai moral sehingga menjadi karakter dalam dirinya, seseorang yang memiliki karakter dalam dirinya akan memiliki etika dan moral yang baik. Namun tidak semua perilaku baik yang dimiliki seseorang, menjamin seseorang tersebut memiliki karakter yang sadar menghargai pentingnya nilai-nilai kaidah moral. Hal ini dapat dimungkinkan apa yang diperbuat dan dilakukan seseorang tersebut bukan didasari dari kesadaran dan pemahaman yang utuh dalam mengenal dirinya, perbuatan yang didasari oleh rasa takut atau kepentingan lainnya itu bukan karena tingginya penghargaan akan nilai-nilai karakter. Dengan demikian seseorang tersebut belum dikatakan berkarakter sekalipun bertindak dan bersikap baik.

Kata karakter sering dihubungan dengan kata etika, moral dan akhlak, maka penulis perlu untuk membedakan kata yang sering dianggap sama dalam berbahasa. Istilah Etika berasal dari bahasa Yunani kuno yang sudah mulai dibicarakan ketika masa Socrates (469-399 SM), Plato (427-347 SM) dan Aristoteles (394-322 SM) disamping Stoich dan Epicures (Mubarok Ahmad:2009). Karl Barth berpendapat Etika berasal dari ethos yang merupakan bentuk tunggal yang bisa memiliki banyak arti baik tempat tinggal yang biasa, padang rumput, kandang, kebiasaan, adat, watak, perasan, sikap dan cara berpikir yang sebanding dengan moral dari kata mos. Bentuk jamaknya adalah ta etha yang berarti adat kebiasaan atau sitten (Majid Nurcholis:2008). Kata Etika jika ditinjau dari sudut pandang epistimologi, maka etika dapat diartikan sebagai ajaran tentang baik dan buruk, benar dan salah yang dilakukan dalam kehidupan manusia. Etika merupakan konsep-konsep yang berhubungan dengan tingkah laku dan perbuatan manusia dalam kerangka pemikiran, adat, kebiasaan dan prilaku seseorang dari lingkungan budaya tertentu. Franz Magnis Suseno menyebutkan etika sebagai ilmu yang mencari orientasi bagi usaha manusia untuk menjawab pertanyaan yang amat fundamental, "Bagaimana manusia harus hidup dan bertindak?" (ElMubarok Zaim:2008).Untuk memahami lebih dalam apa yang terkait dengan standarisari yang termasuk didalam, etika adalah bagaimana manusia itu mencintai terhadap ssesama manusia bukan cinta pada keinginan sendiri, karena suatu perbuatan yang didasari atas keinginan atau kepentingan untuk diri sendiri, mencintai 
sesama manusia dengan memanusiakan manusia dengan didasari cinta kepada Tuhan yang menciptakan semua mahkluk di bumi. Dengan kata lain adalah mencintai semua yang diciptakan Tuhan dengan ketulusan hati bukan kepentingan pribadi atau golongan, bukan pula karena hawa nafsu atau kebanggaan, fanatisme kekeluargaan atau kesukaan.

Selain etika ada juga moral yang sering di uangkapkan dengan maksud yang sama, lantas apa yang dimaksud dengan moral. Kata moral dalam bahasa Indonesia berasal dari bahasa Latin yaitu mores yang diartikan adat kebiasaan. Kata mores ini mempunyai sinonim mos, moris, manner mores, atau manners, morals. Kata moral berarti akhlak atau kesusilaan yang mengandung makna tata tertib batin atau tata tertib hati nurani yang menjadi pembimbing tingkah laku batin dalam hidup (Djatnika Rachmat:1996). Moral merupakan dorongan dalam diri seseorang untuk melakukan sesuatu yang berkaitan dengan prinsipprinsip nilai dan etika yang berlaku. Seseorang yang memiliki moralitas tentunya mengetahui akan standar nilai yang berlaku dan diyakini dirinya, sehingga dapat membedakan baik dan buruk, benar dan salah, patut dan tidak patut. Pada dasarnya setiap manusia memiliki fitrah yang sama, yaitu memiliki kecintaan terhadap kebenaran dan selalu mencari kebenaran. Semakin besar rasa keinginan tahuan dan mengetahui akan nilai dari kebenaran, maka seseorang tersebut akan memiliki moralitas yang baik. Moral dan etika selain memiliki konotasi maknanya yang serupa dan sangat dekat, namun juga tetap memiliki perbedaan. Kedua kata tersebut sering diidentikkan dengan kata akhlak, tetapi terdapat penekanan dalam memahami kata tersebut, moral dapat dihubungkan dengan kesusilaan atau perilaku susila, sehingga moral berada dalam tataran terapan. Sedangkan makna etika dapat dipahami sebagai tataan konsep atau pengetahuan. Sedangkan makna moral merupakan suatu perbuatan pratiktal dari penjabaran tentang etis atau tidak etis, manusiawi atau tidak manusiawi, layak atau tidak layak, elok atau tidak elok. Jika seseorang memiliki moral yang baik dalam menjalankan kehidupannya, ia mampu memanusiakan manusia, maka seseorang tersebut dapat dikatakan bermoral. Sebaliknya jika seseorang mengetahui tentang konsep dan nilai-nilai etika, namun dalam bersikap dan bertingkahlaku tidak mampu membedakan yang baik dan buruk, benar dan salah sehingga tidak dapat memanusiakan manusia maka seseorang tersebut amoral.

Berdasarkan definisi yang sudah di paparkan maka dapat dikatakan bahwa Pendidikan Karakter membutuhkan aspek perasaan (emosional), kecerdasan emosional pada diri manusia agar mampu mengarahkan sikap dan tingkah-laku manusia menjadi berkarakter. Lickona (1992) menyebutkan "desiring the good" atau keinginan untuk melakukan kebajikan. Dalam hal ini ditegaskan bahwa pendidikan karakter yang baik harus melibatkan bukan saja aspek "knowing the good", tetapi juga "desiring the good" atau "loving the

JECIES: Journal of Early Childhood Islamic Education Study 
good", sehingga manusia tidak berperilaku seperti robot yang diindoktrinasi oleh paham tertentu. Ketiga komponen yang dijelaskan oleh Lickona sangat penting untuk pahami agar memiliki karakter yang baik (components of good character), yang dimaksud dengan moral knowing berkaitan dengan moral awereness, knowing moral values, persperctive talking, moral reasoning, decision making dan self-knowledge. Moral feeling berkaitan dengan conscience, self-esteem, empathy, loving the good, self-control dan humilily ; sedangkan moral action merupakan perppaduan dari moral knowing dan moral feeling yang terwujudkan dalam bentuk kompetensi (competence),keinginan (will), kebiasaan (habit). Dari ketiga komponen tersebut diatas merupakan indikator yang harus di perhatikan dalam pendidikan karakter, sehingga anak didik yang akan diberikan pendidikan, pengajaran, pemahaman tentang dirinya dalam kehidupan mampu menyadari tentang nilai-nilai kebajikan secara utuh dan menyeluruh (Mulyasa. E :2011).

Pendidikan karakter sesungguhnya sudah ada sejak dahulu kala, dalam perspektif Islam pendidikan karakter secara teoretik sebenarnya telah ada sejak Nabi Muhammad SAW di utus kemuka bumi ini untuk menyempurnakan akhlak manusia. Pemahaman tentang ajaran Islam tidak hanya terfokus pada permasalahan aqidah, ibadah dan mu'amalah, melainkan hal yang tidak kalah penting adalah ajaran tentang akhlak. Akhlak tidak hanya memahami seni dalam kehidupan yang mengajarkan tentang cara hidup bahagia atau bagaimana mendapatkan kebahagian. Namun akhlak merupakan ilmu pengetahuan yang harus dipelajari dan dipahami dengan benar sehingga dapat dilaksanakan dan diamalkan dalam kehidupan sehingga dapat menjadi bukti kualitas keimanan seorang hamba.

Ibnu Miskawih dalam Tahzibul Akhlak, al-Farabi dalam Tahshilus Sa'adah, dan al-Amiri melalui as-Sa'adah wal Is ad-nya menjelaskan bahwa akhlak yang baik adalah salah satu cara untuk mendapatkan kebahagian, karena memang kebahagian merupakan tujuan utama akhlak Dalam mengartikan akhlak sudah banyak para ilmuwan yang mendefinisikannya, al-Ghazaly mengartikan akhlak "Sifat yang tertanam dalam jiwa yang menimbulkan macam-macam perbuatan sengan gampang dan mudah tanpa memerlukan pemikiran dan pertimbangan atau tanpa dihitung resikonya" dan Ibnu Miskawih "Sifat yang tertanam dalam jiwa yang mendorongnya untuk melakukan perbuatan tanpa memerlukan pemikiran dan pertimbangan". (Kartanegara Mulyadi:2005).

Pada hakikatnya Pendidikan karakter adalah proses pendidikan yang menanamkan nilai-nilai etika serta moral, hingga pada akhirnya akan menjadi kebiasaan (habit) yang terpatri dalam diri generasi bangsa, sebagai anak bangsa yang akan melanjutkan perjuangan dan masa depan bangsa lebih baik lagi serta memiliki identitas kebangsaan yang dapat mengharumkan nama bangsa. Proses 
pendidikan karakter yang dilaksanakan secara sitematis dan terorganisir memiliki maksud dan tujuan, untuk menciptakan generasi bangsa yang memiliki karakter bangsa. Pendidikan karakter bangsa di Indonesia telah berlangsung jauh sebelum Indonesia merdeka. Ki Hajar Dewantara yang dinobatkan sebagai Pahlawan Pendidikan Nasional memiliki pandangan tentang karakter sebagai Asas Taman Siswa 1922 dengan tujuh prinsip sebagai berikut :.

1. Hak seseorang untuk mengatur diri sendiri dangan tujuan tertibnya persatuan dalam kehidupan umum.

2. Pengajaran berarti mendidik anak agar merdeka batinnya, pikirannya, dan tenaganya.

3. Pendidikan harus selaras dengan kehidupan.

4. Kultur sendiri yang selaras dengan kodrat harus dapat memberi kedamaian hidup.

5. Harus bekerja menurut kekuatan sendiri.

6. Perlu hidup dengan berdiri sendiri.

7. Dengan tidak terikat, lahir batin dipersiapkan untuk memberikan pelayanan kepada peserta didik (Mulyasa. E :2011).

Dalam Asas Pendidikan Taman Siswa yang didirikan oleh bapak pendidikan nasional, bermaksud ingin mendidik manusia Indonesia menjadi manusia yang seutuhnya (kaffah), dengan harapan para generasi bangsa selanjutnya dapat hidup mandiri, efektif, efisien, produktif dan akuntabilitas. Harapan yang dimiliki oleh Ki Hajar Dewantara bukanlah hal yang mudah untuk di pratekkan, dibutuhkan kerjasama dalam proses mendidik generasi bangsa, pembekalan dasar-dasar kehidupan agar memiliki kesadaran, pemahaman, kepedulian dan komitemen yang tinggi, sehingga dapat terwujudnya masyarakat yang aman dan damai.

\section{Pendidikan Anak Usia Dini}

Proses pendidik anak dimasa usia dini merupakan bagian yang sangat penting dalam pendidikan Islam, pendidikan anak dalam Islam yang disebut dengan Tarbiyatul 'l-Aulad fi 'l-Islam. Proses pendidikan dimasa usia dini terhitung pada 0-6 tahun, sedangkan pada pendidikan Islam proses pendidikan anak dimulai bukan pada rentang 0-6 tahun namun dimulai pada ikatan pernikahan kedua orang tuanya. Hubungan orang tua dalam ikatan suami dan istri yang akan membuahkan dan menghasilkan anak yang baik dan berkualitas. Pada proses menjalani hubungan keluraga ini maka pemahaman suami dan istri harus berlandasakan pendidikan agama, sehingga dalam proses pendidikan anak usia dini akan dapat menghasilkan generasi yang daya guna dan berlandaskan aqidah Islamiah. Keberhasilan pendidikan menurut Cornelius- 
White (2007) yang dikutip oleh Shulman menyatakan bawa kehangan, antusiasme dan kepedulian memiliki peranan sangat penting. Tetapi keberhasilan penyelesian semua tugas mengajar itulah yang dapat menghasilkan kefektifan pengajaran (Shulman : 2000).

Dalam hal ini pendidikan orang tua dalam memahami peranannya sebagai orang tua didalam hubungan berkeluarga, tentunya akan menjelasakan dan meningkatkan pendidikan anak pada masa perkembangnya. Sangat erat hubungannya kualitas pemahaman orang tua dalam hubungan berkeluarga, yang nantinya akan berdampak dalam proses perkembangan anak yang akan dihasilkan dalam hubungan suami dan istri, sehingga proses pendidikan anak akan berjalan dengan optimal dan maksimal. Hubungan keluaraga yang sehat dan memahami ajaran agama tentunya akan mempermudah proses pendidikan anak usia dini, pasangan suami dan istri akan saling bahu membahu dalam membina dan mendidik anak-anak. Saling membantu dan bahu membahu menjalankan hubungan berkeluarga hendaklah berlandaskan pendidikan Islam yang berdasarkan Al-Quran, sehingga kedua orang tua tidak akan lalai dalam mendidikan dan menjalankan amanah yang telah Allah SWT berikan kepada manusia yang merupakan mahluk sempurna dan ditugaskan menjadi kholifah dimuka bumi ini. (Hidana Rudi : 2020) perkembangan manusia merupakan usaha yang terus berlangsung dan berkembang.

Dalam ajaran agama Islam pendidikan akan dimulai dari dalam keluarga yang memiliki peranannya masing-masing dalam membina dan memikul tanggung jawab dalam hubungan berkeluarga, masing-masing keduanya akan saling melengkapi dan menyempurnakan tugas dan tanggung jawab. Dalam pendidikan Islam disebutkan bahwa ibu merupakan pendidikan pertama bagi anak-anaknya, ibu yang merupakan pendidik pertama dan utama dalam proses pendidikan dan perkembangan anak-anaknya baik secara fisik, motorik, kognitif, sosial-emosional, spiritual maupun bahasa dan lainnya. Dikarenakan ibu merupakan pendidik pertama dan utama maka sosok ibu haruslah memiliki keteladanan dan memahami perannya sebagai pendidik yang pertama dan utama bagi anak-anaknya, Ibu yang akan menjalankan peran terpenting dalam pendidikan keluaraga dan anak-anaknya, sehingga pada masa usia dini proses pertumbuhan dan perkembangan anak akan mampu berkembang dan belajar banyak hal dari ibunya sebagai sumber pengetahuan yang pertama dan utama.

Tentu tepatlah sebuah ungkapan yang dikatakan bahwa ibu adalah sebuah sekolah pertama bagi anaknya. Apabila engkau persiapkan dia (Anak Perempuan), berarti engkau telah mempersiapkan suatu bangsa yang mempunyai dasar yang baik. Sehingga dapat dikatakan bahwa dalam pendidikan Islam, pendidikan dimulai dari pendidikan keluarga yaitu pendidikan seorang ibu yang akan menciptakan generasi penerus bangsa yang

JECIES: Journal of Early Childhood Islamic Education Study 
memiliki dasar yang baik dan berkualitas. Ibu adalah sosok wanita yang akan menciptakan generasi penerus hendaklah selalu meningkatkan pengetahuan dan intelektual dirinya sehingga mampu menjadi pendidik yang pertama dan utama bagi anak-anak dalam proses pendidikan dan perkembangnnya. Allah SWT telah menganugerahkan kepada kedua orang tua rasa cinta untuk anaknya. Seperti yang telah diketahui bahwa hati manusia yang terikat dalam hubungan suami dan istri diberikan fitrah untuk mencintai anaknya dan tumbuh perasaan-perasaan kejiawaan yang akan melatarbelakangi perkembangan dan pertumbuhan sang anak. Sehingga sudah jelaslah bahwa dalam pendidikan Islam peran orang tua memiliki fungsi yang natural dalam proses menstimulus pendidikan anak dengan diberikan fitrah dan rasa cinta dalam mendidik dan membimbing anak-anaknya. Firman Allah SWT:

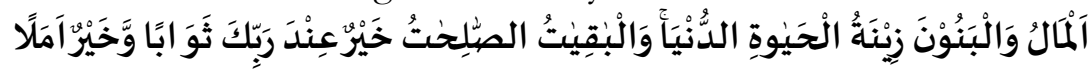
"Harta dan anak-anake adalah perbiasan kehidupan dunia tetapi amalan-amalan yang kekeal lagi saleh adalah lebih baik pahalanya di sisi Tuhanmu serta lebih baik untuk menjadi harapan” (Q.S. al-Kahf :46 )

Fitrah yang Allah SWT berikan kepada manusia merupakan kewajiban dan tanggung jawab untuk membesarkan, mendidik, memelihara dan memperhatikan anak-anak mereka dengan penuh kasih sayang dan cinta. Dengan cinta dan kasih yang diberikan, mereka dapat tumbuh dan berkembang dengan sehat lahir batin. Anak yang mendapatkan cinta kasih di lingkungan keluarga akan tumbuh dengan kebahagian dan mereka akan memberikan energi positif pada lingkungan sosial sekitarnya. Fitrah ini merupakan anugrah yang tidak terhingga dalam proses pendidikan dan perkembangan sang anak menuju perkembangan kepribadian mereka dan sampai dewasa, proses pendidikan yang dipenuhi dengan rasa kasih dan sayang serta cinta akan berdampak pada kepribadian sang anak. Allah SWT menjadikan manusia berpasang-pasangan untuk beribadah dan menjalankan tugasnya sebagai seorang hamba yang akan mengemban amanah di dunia dan akan memakmurkan dunia dengan diberikan anugrah anak dalam keluarga yang mereka bina.

Proses perkembangbiakan ini merupakan fenomena yang terjadi dan terus terjadi sampai akhir masa yang telah Allah SWT tetapkan, maka pada masa proses tersebut tugas dan tanggung-jawab orang tua dalam mendidik anaknya akan terus terlaksana hingga terselesaikan kehidupan di dunia. Orang tua yang menjadi pendidikan bagi anak-anak di masa pendidikan keluraga tentunya akan berperan banyak dalam membentuk kepribadian dan karakter sang anak. Dekadensi moral saat ini terjadi karena lemahnya pendidikan keluarga yang seharusnya menjadi pendidikan pertama bagi anaknya dalam menjalankan amanah dan tanggung jawab sebagai orangtua. Di dalam

JECIES: Journal of Early Childhood Islamic Education Study Vol. 02, Nomor 01, Maret 2020 
pendidkan Islam tanggung jawab terbesar bagi para pendidik diantaranya, adalah : Pendidikan Iman, Pendidikan Akhlak, Pendidikan Fisik, Pendidikan Intelektual, Pendidikan Psikologis, Pendidikan Sosial, Pendidikan Seksual (Ulwan. Abdullah Nashih:1991).

\section{Pendidikan Iman}

Yang dimaksud dengan Pendidikan Iman adalah bagaimana tanggung jawab terbesar bagi seorang pendidik untuk memberikan pemahaman dalam hal keimanan, pendidikan iman adalah mengikat anak dengan dasardasar Iman, Rukun Islam dan dasar-dasar Syari'ah. Dimulai saat anak mulai mangerti dan dapat mamahami sesuatu. Pendidikan iman merupakan pendidikan paling dasar yang harus di ketahui oleh sang anak pada masa usia dini. Ketika sang ibu mengandung pendidikan iman ini sudah mulai diajarkan oleh ayah dan ibunya, ketika dalam kandungan pendidikan iman dapat diajarkan dengan pembiasaan dan prilaku ibunya. Usia 0-6 tahun masa sang anak akan tumbuh dan berkembang sehingga dapat menghasilkan pengetahuan yang akan berkesinambungan hingga sang anak dewasa. Dengan dasar keimanan yang di miliki sang anak kiranya sang anak akan menicntai dan mengetahui Tuhannya dan menjadi generasi yang islami dengan dasar ke imanan yang kuat.

\section{Pendidikan Akhlak}

Pendidikan Akhlak merupakan pendidikan juga tidak kalah pentingnya yang menjadi tanggung jawab terbesar bagi pendidik dalam mendidik dan mengembangkan pengetahuan sang anak, pendidikan akhlak merupakan pendidikan yang akan mengarahkan serta mendidik anak menjadi anak yang bermoral dan berakhlak mulia. Sehingga kelak sang anak akan mampu memaksimalkan akal budi mereka sehingga sang anak memiliki moral dan beretika yang sesuai dengan apa yang telah diberikan oleh orang tuanya pada masa pertumbuhan sang anak. Dekadensi moral yang terjadi saat ini merupakan hasil dari pendidikan yang terjadi di dunia pendidikan, baik penidikan keluarga, pendidikan sekolah atau pendidikan sosial masyarakat. Pendidikan yang hendaknya saling berkesinambungan antara trilogi pendidikan sehingga dapat terjalin komunikasi yang efektif dalam menciptakan generasi penerus bangsa yang bermartabat dan berakhlak mulia. Maka untuk menciptkan bangsa yang besar dan memiliki generasi unggul yang berkualitas, harus dipahami bahwa pendidikan akhlak merupakan pendidikan yang harus menjadi perhatian wajib bagi para pendidik.

Dalam masa usia dini yang sangat sensitive ini pendidikan akhlak merupakan arah yang akan menjadikan pribadi yang berkarakter, dikarenakan pada masa perkembangan jikalau pendidik tidak mendidik dan mengajarkan bagimana cara bersikap dan prilaku benar dan takut pada 
Allah SWT, maka tidak diragukan lagi bahwa secara berkala dan bertahap anak akan melakukan penipuan, pencurian dan pengkhianatan. Untuk itu para pendidik dan orangtua sudah seharusnya memberikan pendidikan akhlak dan menanamkan akidah pada anak mulai sejak sedini mungkin.Pendidikan akhlak ini tidaklah mudah di ajarkan pada anak terutama pada masa usia dini, sehingga sudah menjadi keharusan bahwa pendidik dan orangtua menjadi sumber kebenaran yang utama bagi sang anak. Dengan memberikan keteladan yang baik bagi sang anak, baik dalam keiindahan bahasa sampai dalam hal bergaul dan bersosialisasi dengan kawann sejawat. Selain keteladan pendidik dan orangtua harus mejelaskan kepada anka-anak akan sebab akibat yang akan mereka tanggung yang ditimbulkan dari kecerobohan dalam bertingkah laku dan bersikap. Pada masa usia dini pula anak-anak harus di latih untuk tidak bersifat dan berprilaku hedonis, mereka harus diajarkan untuk bersikap peduli dan prihatin dengan kondisi dang keadaan sekitar mereka.

\section{Pendidikan Fisik}

Pendidikan Fisik dapat juga dikenal pendidikan perkembangan motorik pada anak usia dini. Pendidikan ini juga merupakan pendidikan yang harus diberikan pada anak usia dini secara bertahap dalam proses perkembangan anak manusia. Bagi para pendidik, pendidikan fisik ini berhubungan dengan tumbuh kembang sang anak dan gizi yang didapatkan oleh sang anak, dengan pendidikan fisik dan pemberian gizi yang baik dan benar akan menjadikan sang anak generasi yang sehat jasmani dan rohaninya sehingga mampu menjadi generasi yang bermutu dan berkualitas. Dalam mengembangkan tumbuh kembang anak, seorang pendidik hendaknya memberikan dan mencurahkan perhatian dan tanggung jawab secara menyeluruh dan optimal dalam proses perkembangan fisik. Sehingga sang anak mampu dibina dan diarahkan dengan kondisi fisik yang baik dan sehat. Fisik merupakan bagian yang sangat penting, dengan sehat dan baiknya fisik sang anak tentunya dalam segala proses pendidikan sang anak akan mampu memaksimalkan potensi mereka tanpa terdapat hambatan fisik yang lemah. Pemberian stimulus dalam penguatan otat kasar dan halus juga perlu menjadi perhatian bai para pendidik.

Pendidikan fisik ini tentunya berhubungan dengan tugas ayah sebagai pemberi nafkah bagi keluarganya, nafkah yang diberikan oleh ayah akan menghasilkan anak yang di harapakan. Maka dalam pendidikan Islam dianjurkan untuk mencari nafkah dan harta yang halal sehingga mendapatkan keberkahan didalamnya dan tentunya akan berdampak pada perkembangan fisik sang anak yang diberikan nafkah tersebut. Harta yang halal tentunya akan menjadi jalan yang benar dalam perkembangan sang anak mulai dari usia dini hingga dewasa. Sangat erat hubungannya nafkah 
yang halal dalam perkembangan fisik anak, didalam ajaran agama Islam nafkah yang halal akan menghasilkan darah yang halal serta gizi yang halal untuk anaknya, sehingga apa yang menjadi asupan makanan bagi sang anak akan berdampak pada diri sang anak dimasa pertumbuhannya hingga dewasa kelak. Maka tugas ayah yang mencari nafkah untuk keluarganya sangat penting memperhatikan ke halal dari apa yang dicarinya. Sehingga proses pendidikan fisik pada anaknya akan mudah diarahkan dan dibina dengan baik oleh para pendidik. Sangat jelas diterangkan didalam agama Islam bahwa semua yang baik akan menghasilkan kebaikan pula didalam diri dan keluarganya, maka perlu menajdi perhatian yang sangat khusus terkait dengan cara dan proses mendapatkan nafkah bagi sang ayah.

\section{Pendidikan Intelektual}

Pendidikan yang juga tidak kalah pentingnya, yang harus diberikan pada anak sejak masa usia dini adalah Pendidikan Intelektual. Pendidikan Intelektual ini sangat penting, dikarenakan pendidikan ini merupakan pendidikan yang akan meningkatakan kecerdasan intelektual mereka mulai sedini mungkin. Pendidikan intelektual merupakan pendidikan yang harus diperhatikan oleh orangtua dan pendidik dalam tumbuh kembang sang anak. Pendidikan ini merupakan modal yang penting bagi sang anak mana kala mereka dewasa kelak, dengan intelektual yang baik tentunya sang anak akan mampu menjawab dan menyelesaikan tantangan kehidupan yang akan dihadapinya. Perkembangan daya kognitif pada anak usia dini dimasa keemasan tentu membutuhkan strategi pembelajaran yang kreatif dan inovatif. Seiring dengan perkembangan zaman, anak usia dini saat ini memiliki kemampuan daya analisis yang kritis. Perubahan tersebut dikarenakan mudahnya informasi didapat setiap orang termasuk anak usia dini, dengan kecangihan teknologi. Oleh sebab itu, pendidik hendaknya menyesuaikan dengan kebutuhan zamannya, sebagimana Ali bin Abi Tholib berkata "Didiklah Anak-anakmu sesuai dengan zamannya, karena mereka bukan di zamanmu".

Pendidikan intelektual ini akan membentuk dan membina cara berpikir anak dengan segala yang ada dan mungkin ada dengan segala sesuatu yang bermanfaat, ilmu pengetahuan dan ilmu peradaban akan mereka pahami mulai sejak dini, cara berpikir yang positif akan menjadikan sang anak tumbuh dan berkembang sesuai dengan optimal dan maksimal. Cara berpikir yang baik dan berbudaya akan membantu menciptakan generasi unggul berkarakter. Setiap anak yang terlahir didunia ini berhak mendapkan pendidikan Intektual yang layak yang bermutu, dalam amanah UUD 1945 setiap anak berhak mendapatkan pendidikan yang layak dan berkualitas. Begitu pula dalam pendidikan agama Islam, setiap anak berhak mendapatkan pengetahuan yang dibutuhkannya dalam rangka 
mendewasakan dan menjadi manusia yang berbudaya dan berintelektual. Untuk menciptakan generasi unggul yang berpengetahuan luas, berbudaya dan berintelektual sangat penting peran serta orangtua dan pendidik dalam membina dan mengembangkan pendidikan intelektual pada diri sang anak. Pendidikan Intelektual merupakan pendidikan yang mengoptimalkan fungsi dari akal yang merupakan anugrah dari Allah SWT, Memfungsikan akal secara efektif dan baik tentunya kita sudah mensyukuri anugrah yang diberikan Allah SWT kepada kita. Disinilah kita akan meningkatkan segala potensi akal yang menjadi salah satu sumber pengtahuan yang dapat meberi nilai secra objektif.

\section{Pendidikan Psikologis}

Pendidikan selanjutnya yang perlu menjadi perhatian para pendidik dan orangtua adalah Pendidikan Psikologis. Pendidikan ini berhubungan dengan kejiwaan sang anak agar kecerdasan "sosial emosional" anak dapat tumbuh dan berkembang sesuai dengan potensi yang dimiliki dalam diri sang anak. Pendidikan psikologis pada anak bertujuan untuk membentuk, menyempurnakan dan menyeimbangkan kepribadian pada diri anak. Anak yang tumbuh dengan pendidikan psikologis yang baik, akan mudah diterima dalam lingkungan pergaulan sehari-hari, dikarenakan sifat minder, sifat penakut, sifat rendah diri, sifat hasud dan sifat pemarah tidak ada dalam diri sang anak, kalau pun ada mereka mampu mengkontrol dengan kecerdasan sosial emosional mereka. Pendidikan psikologis merupakan pembinaan dalam diri sang anak yang dimulai sejak anak usia dini, pendidikan yang dimulai pada saat anak dalam alam Rahim sampai anak tumbuh dan berkembang secara nalar logikanya. Anak yang terdidik dalam kecerdasan social emosional ini akan mampu menyelesaikan segala permasalahan yang dihadapinya, mereka akan berani dan mengemukakan segala gagasan dan ide cemerlang dan baru.

\section{Pendidikan Sosial}

Selanjutnya Pendidikan Sosial, pendidikan ini akan mengajarkan pada diri anak hubungan sosial dengan lingkungan sekitarnya. Pendidikan sosial mengajarkan anak tentang kebiasaan agar terbiasa menjalankan adab sosial yang baik dan dasar-dasar psikologis yang mulia yang bersumber pada akidah Islamiyah.Tidak dapat dipungkiri bahwa pendidikan ini merupakan pendidikan yang merupakan tanggung jawab terpenting dari beberapa pendidikan yang sebelumnya telah kita ketahui bersama. Pendidikan sosial merupakan manifestasi perilaku dan watak serta karakter anak telah dididik oleh orang tua atau pun pendidik. Melalui pendidikan sosial, anak akan mampu menjalani hak-hak, tata-krama, kritik sosial, keseimbangan intelektual, politik dan pergaulan serta hubungan yang baik dengan orang lain. 
Dalam menciptakan anak-anak yang siap dengan segala kondisi yang ada, maka anak harus dipersiapkan sedini mungkin untuk menerima ketetapan eksperimental dan faktual sehingga pertumbuhan dan perkembangan anak mulai sejak dini akan mampu menjawab tantangan zaman yang kian pelik dan kompleks. Pendidikan sosial yang menjadikan solusi dalam perkembangan dan pembinaan anak yang siap serta berdaya guna dan diterima oleh masyarakat dimanapun meraka berada, sehingga pada saatnya nanti sang anak akan terbiasa dan terdidik dalam bergelut didalam kehidupan bersosial di masyarakat, meraka akan memberikan gambaran yang benar tentang insan yang sempurna, seimbang, memiliki nalar logika yang baik serta bijaksana. Oleh karena itu tanggung jawab pendidikan sosial ini berusaha dengan keras serta penuh dedikasi untuk mempersiapkan sang anak menjadi manusia yang dapat bermanfaat dan manusia yang mampu menjawab tantangan kehidupannya.

\section{Pendidikan Seksual}

Pendidikan yang tidak kalah penting adalah Pendidikan Seksual, yang dimaksud dengan pendidikan seksual adalah upaya pengajaran dan pendidikan tetang masalah-masalah yang berkenaan dengan seksual yang diberikan kepada anak, sejak mereka sudah mulai memahami. Pendidikan seksual yang harus mendapatkan perhatian secara khusus dari para pendidik, dilaksanakan berdasarkan fase-fase sebagai berikut :

a. Fase usia 7-10 tahun, disebut masa tamyiz (masa pra-pubertas), pada masa ini, anak diberi pelajaran tetang etika meminta izin dan memandang sesuatu.

b. Fase usia 10-14 tahun, disebut masa murahaqah (masa peralihan atau pubertas) pada masa ini, anak dijauhkan dari berbagai rangsangan seksual

c. Fase usia 14-16 tahun, disebut masa bulugh (masa adolesen), pada masa ini jika anak sudah siap untuk menikah, maka berikanlah pelajaran tetang etika (adab) mengadakan hubungan seksual.

d. Fase selanjutnya setelah masa adolesen, disebut masa pumuda, pada masa ini anak diberi pelajaran tentang adab (etika) melakukan isti'faf (bersuci), jika memang ia belum mampu melangsungkan pernikahan (Ulwan. Abdullah Nashih:1991).

Sangat penting diajarkan kepada anak tentang pendidikan seksual, sehingga mereka tidak mempelajari masalah-masalah seksual tanpa bimbingan dan arah pendidik atau orang tua. Dalam ajaran agama Islam semua pendidikan hendaklah diberikan kepada anak mulai sejak dini hingga mereka mampu berdikari dan mandiri. Hingga waktunya mereka menjadi manusia dewasa mereka akan memahami dan mengetahui apa yang akan dilakukan dan harus dilakukan dengan baik dan benar sesuai 
dengan anjuran dalam pendidikan Islam. Karena tujuan dalam pendidikan adalah mendidik, mengarahkan, membina dari yang tidak tahu menjadi tahu, dari yang tidak bisa menjadi bisa, dari yang tidak mengerti menjadi mengerti, dari yang tidak faham menjadi faham sehingga mereka dapat tumbuh menjadi manusia dewasa.

\section{Pendidikan Untuk Menciptakan Generasi Unggul}

Pendidikan merupakan cara yang sangat efektif dalam pembangunan suatu bangsa, sebagaimana telah dibahas sebelumnya. Pendidikan mempunyai peranan yang sangat penting dan strategis, maka berdasarkan hal tersebut tuntunya pendidikan dalam menciptakan generasi harapan bangsa hendaknya didukung penuh oleh pemerintah selaku pemangku kebijakan dalam pembangunan dunia pendidikan nasional. Pemerintah yang mengatur dan merencanakan masa depan generasi bangsa, hendaknya memiliki tekad yang kuat dan memberikan perhatian yang sangat besar pada pembangunan dan pengimplentasian program dan kebijakan dalam mendukung tujuan pendidikan nasional. Pentingnya pendidikan dalam suatu pembangunan bangsa maka dunia pendidikan hendaknya didukung oleh semua lapisan masyarakat dengan tumpuan tanggung jawab utama pelaksanaan pendidikan berada pada pemerintah (UUD 1945-Pasal $31: 1$ ).

Untuk menghasilkan generasi unggul harapan bangsa yang sesuai dengan identitas bangsa, tentunya membutuhkan pendidikan yang kuat dan berkarakter. Ukuran keberhasilan pembangunan suatu bangsa tidak hanya diukur pada tingginya pendapatan perkapita, tapi lebih mendasar lagi yaitu bagaimana keaman dan kedamain dalam suatu bangsa itu dapat dirasakan oleh seluruh lapisan masyarakat tanpa terkecuali. Karakter yang dimiliki masayakat yang berperadaban dan berintelektual, sehingga suatu bangsa memiliki harkat dan martabat yang tinggi dalam suatu peradaban. Untuk mendukung keberhasilan dalam menciptakan generasi unggul, dibutuhkan revitalisasi pendidikan sejak anak usia dini dan kesadaran secara kolektif dan holistik. Pendidikan holistik juga dapat diartikan sebagai proses pendidikan yang berusaha mengembangkan manusia secara utuh, yang meliputi pengembangan intelektual, emosional, fisik, sosial, estetika dan spiritual (John P. Millir, dkk :2005).

Pendidikan holistik yang dilaksanakan dan disadari oleh setiap elemen trilogi pendidikan, membutuhkan pendidikan karakter yang ditanamkan sejak usia dini. Pendidikan holistik yang berbasis karakter bertujuan untuk mengkontruksikan seluruh dimensi manusia dengan berbagai pendekatan pada pengalaman belajar yang menyenangkan, kreatif dan inspiratif untuk anak didik. Dalam konteks pendidikan holistik untuk mendukung terciptanya generasi unggul, guru akan diperlengkapi dengan pengetahuan teoritis dan 
praktis mengenai pendidikan yang patut dan menyenangkan, pembelajaran yang ramah otak, kecerdasan emosi, komunikasi efektif, penerapan pendidikan sembilan pilar karakterr secara ekplisit (mengetahui, merasakan dan melakukan), kecerdasan majemuk, pembelajaran kooperatif, pembelajaran kontekstual, pembelajaran berbasis pertanyaan, manajemen kelas efektif, pembelajaran siswa aktif, whole language, aplikasi modul pendidikan holistik berbasis karakter, aplikasi model karakter di ruang kelas, teknik bercerita, kreativitas dan lain-lain. Model pendidikan holistik berbasis karakter adalah model pendidikan yang tidak hanya memberikan rasa aman untuk siswa, tetapi juga menciptakan suasana belajar yang nyaman dan menstimulasi suasana belajar siswa (Rubiyanto Nanik dan Haryanto Dany: 2010).

Zaman Millenial yang menghantarkan perubahan besar dalam perkembangan teknologi, juga membuat perubahan dalam pembelajaran mulai penidikan usia dini hingga pendidikan tinggi. Perubahan zaman ini memiliki harapan baru untuk suatu perubahan yang lebih baik lagi dan terbuka dalam implementasi pendidikan. Perubahan ini diharapkan akan mempermudah pelayanan dan pengembangan pendidikan sesuai dengan kebutuhan zaman, dalam mewujudkan bangsa Indonesia yang mandiri dan berdikari dengan berdaya saing tinggi, tentunya dibutuhkan rencana besar untuk perkembangan anak didik. Suatu rencanan yang besar tentunya dilaksanakan secara sistematis dan terorganisir yang tidak lepas usaha pemerintah sebagai pemangku kebijakan pendidikan nasional.

Terkait dengan pembangunan Sumber Daya Manusia (SDM) yang mampu berdikari serta mandiri, maka dunia pendidikan harus mampu merekonstruksikan secara sistematis dan terorganisir dengan baik, sehingga pendidikan dalam rangka membangun SDM diarahkan akan mampu meningkatkan kualitas sumber daya Indonesia yang di tandai dengan peningkatakan Indeks Pembangunan Manusia (IPM), Indeks Pembangunan Gender (IPG), meningkatkan keseimbangan penduduk dan kestabilan ekonomi (Ali Mohammad:2009). Dalam mewujudkan harapan besar dari tujuan pendidikan nasional, terdapat banyak kendala, diantaranya masih rendahnya kualitas sumber daya manusia Indonesia yang memiliki kesadaran dan kemampuan intelektual. Akibatnya adalah terjadinya ketimpangan outcome dari dunia pendidikan di suatu daerah dengan daerah lainnya. Kesenjangan ini menjadikan dunia pendidikan semakin pelik dalam menyelesaikan kelemahan yang ada.

Tingkat kesadaran dan tingkat intelektual yang dimiliki Indonesia masih belum merata diseluruh wilayah / daerah dipelosok negeri. Kemampuan untuk mampu menguasai dan memahami ilmu pendidikan dan teknologi yang saat ini sudah semakin maju pun masih terdapat kendala. Tantangan pembanguanan dunia pendidikan semakin pelik dan rumit. Pendidikan 
karakter yang ditanamkan pada masa usia dini diharapkan menjadi pondasi yang kokoh yang akan menjawab dan memberikan solusi kemajuan bangsa. Secara konseptual pembangunan adalah segala upaya yang dilakukan secara terencana dalam melakukan perubahan dengan tujuan utama memperbaiki dan meningkatkan taraf hidup masyarakat, meningkatkan kesejahteraan dan meningkatkan kualitas masyarakat (Ali Mohammad:2009). Dalam mengimpelementasikan perubahan yang lebih baik dengan perbaikan taraf hidup dan kualitas manusia yang berkarakter, memerlukan prakondisi yaitu infrastruktur, sarana dan prasarana yang semuanya dapat memberikan pengaruh dalam mobiltas kemajuan peradaban dan perkembangan secara nyata dalam peningkatan harkat dan martabat bangsa.

Dalam memahami terkait dengan meningkatnya harkat dan martabat bangsa ditentukan oleh berbagai macam indikator yang akan sangat berhubungan, diantaranya adalah kemampuan dalam bidang kompetensi, prilaku positif dalam berhubungan dengan lingkungan alam dan masyrakatnya. Maka sangat dibutuhkan manusia-manusia yang berkarakter untuk membangun suatu peradaban disuatu banga. Bangsa yang berperadaban tentunya memiliki generasi-generasi yang memiliki rasa cinta tanah air, rela berkorban, berkarakter kebangsaan, memiliki kepercayaan diri, bertanggung jawab, berdikari. Generasi yang tulus iklas pada tanah airnya akan menjaga kehormatan bangsanya, mereka akan mampu melahirkan banyak kesadaran pada manusia lainnya, agar dapat sama-sama membangun bangsa yang maju dan berperadaban (Nurmiyanti.L: 2020).

\section{SIMPULAN}

Pembangunan suatu bangsa membutuhkan pendidikan yang bersinergi mulai dari lingkungan keluaraga, sekolah dan masyarakat. Membangun bangsa yang memiliki identitas dan karakter yang kuat sangat membutuhkan program pendidikan yang sistematis dan terorganisir dengan baik. Pemerintah bertanggung-jawab dan memiliki peranan yang sangat penting dalam membentuk suatu konsep pendidikan nasional yang akan direalisasikan pada lembaga pendidikan di seluruh Indonesia. Pembangunan merupakan usaha yang secara terus menerus tiada henti untuk menjadikan bangsa Indonesia yang berkarakter. Salah satu indikator suatu bangsa memiliki perkembangan adalah meningkatnya kesejahteraan masyarakat bukan hanya dari segi ekonomi namun keamanan dan kedamaian disuatu bangsa. Namun dalam membangun bangsa, terdapat berbagai kendala yang dihadapi, diantaranya hadirnya reformasi informasi dan komunikasi pada era globalisasi. Perkembangan yang begitu pesat pada era moderenisasi ini menciptakan kebebasan dalam mendapatkan pengetahuan, kebebasan tersebut akan sulit terdeteksi dengan bijak. Namun kebebasan tersebut dapat dibatasi dengan pendidikan dan moral yang baik,

JECIES: Journal of Early Childhood Islamic Education Study Vol. 02, Nomor 01, Maret 2020 
sehingga mampu menghasilkan masyarakat yang memiliki karakter yang baik dalam turut serta membangun masa depan bangsa. Sebagaimana telah dipahami bersama untuk menciptakan masyarakat yang berkarakter, bangsa ini membutuhkan keseriusan dalam menciptakannya. Pendidikan karakter akan tercipta dengan baik manakala dibangun sejak masa usia dini pada generasi bangsa.

\section{DAFTAR PUSTAKA}

Abdullah Nashih Ulwan (1991), Pedoman Pendidikan Anak dalam Islam. Semarang: Asy Syifa

Abuddin Nata (1997), Filsafat Pendidikan Islam. Jakarta : Logos

Asma Hasan Fahmi (1979), Sejarah dan Falsafat Pendidikan Islam. Jakarta : Bulan bintang

Amsal Bakhtiar (2007), Fisafat Ilmu. Jakarta: Rajawali Pers

Achmad Mubarok (2009), Akblak. Manusia sebagai Konsep Pembangunan Karakter. Jakarta : GMPAM YPC-WAP

Conny Semiawan (1997), Perspektif Pendidikan Anak Berbakat. Jakarta: Grasindo E.Mulyasa (2011), Manajemen Pendidikan Karakter. Jakarta : Bumi Aksara

Faruq Nasution (2011), Antara Pedagoggi, Edukasi dan Tarbiyah, Persamaan dan Perbedaan Paradigm. Jurnal Istigna, Vol.04

Irawati Istadi (2003), Mendidik Dengan Cinta. Jakarta :Pustaka Inti James H.Stronge (2013), Kompetensi Guru-Guru Efektif. Jakarta : Indeks

Jamaal 'Abdur Rahman (2005), Tabapan Mendidik Anak. Bandung : Irsyad Baitus Salam

John P. Millir, dkk, (ed.) (2005), Holistic Learning and Spirituality in Education, cet. I., 2 USA:State University of New York Press

Kamus Besar Bahasa Indonesia online

Leni Nurmiyanti (2020), Si Kecil Bukan Robot (Pedoman Praktis Dalam Mendidik Anak Berdasarkan Pengalaman dan Pendekatan Konseptual). Bandung : Widina Bhakti Persada

Manpan Drajat, Ridwan Effendi (2014), Etika Profesi Guru. Bandung: Alfabeta M. Arifin(1991), Ilmu Pendidikan Islam. Jakarta: Bumi Aksar

Mohammad Ali (2009), Pendidikan untuk Pembangunan Nasional. Bandung : Grasindo

Muhibbinsyah (2010), Psikologi Pendidikan. Bandung : Rosda

M.Ngalim Purwanto (1991), Ilmu Pendidikan Teoritis dan Praktis. Bandung: Rosda

M.Sahlan Syafei (2006), Bagaimana Anda Mendidik Anak. Bogor: Ghalia Indonesia

Mulyadhi Kartanegara (2003), Pengantar Epistimologi Islam. Bandung: Mizan Mulyadi Kartanegara (2005), Panorama Filsafat Islam, cet II. Bandung : Mizan

JECIES: Journal of Early Childhood Islamic Education Study

Vol. 02, Nomor 01, Maret 2021 
Nanik Rubiyanto dan Dany Haryanto (2010), Strategi Pembelajaran Holistik di Sekolah. Jakarta:Prestasi Pustaka

Nanang Fattah (2012), Sistem Penjamin Mutu Pendidikan. Bandung : Rosda

Paulo, Ivan Illich, dkk (2009), Menggugat Pendidikan.Yogyakarta : Pustaka Pelajar

Rachmat Djatnika (1996), Sistem Ethika Islam (Akblak Mulia). Jakarta : Pustaka Panjimas

Uyu Wahyudin, Mubiar Agustin (2011), Penilaian Perkembangan Anak Usia Dini. Bandung: Refika Aditama

Undang-undang No.20 Tahun 2003 tentang, Sistem Pendidikan Nasional. Jakarta : Negara Kesatuan Republik Indonesia

Wan Mohd Nor Wan Daud (2003), Filsafat dan Praktik Pendidikan Islam Syed M.Naquib Al-Attas. Bandung: Mizan

Yahdinil Firda Nadirah (2014), Psikologi Belajar dan Mengajar. Banten: Cahaya Minolta

Zakiah Darajat, Sodali, dkk (1993), Pendidikan Agama Islam. Jakarta : Universitas Terbuka

Zaim Elmubarok (2008), Membumikan Pendidikan Nilai. Bandung :Alfabeta 